Original research article

\title{
How adverse event reporting in the Slovak Republic is influenced by nurse characteristics and working arrangements: a cross-sectional study
}

\author{
Dominika Kalánková ${ }^{1 * \#}$, Marcia Kirwan ${ }^{2 \#}$, Daniela Bartoníčková ${ }^{1,3}$, Radka Kurucová ${ }^{1}$, \\ Katarína Žiaková ${ }^{1}$, Elena Gurková ${ }^{3}$ \\ ${ }^{1}$ Comenius University in Bratislava, Jessenius Faculty of Medicine, Department of Nursing, Martin, Slovak Republic \\ ${ }^{2}$ Dublin City University, School of Nursing and Human Sciences, Dublin, Ireland \\ ${ }^{3}$ Palacký University in Olomouc, Faculty of Health Sciences, Department of Nursing, Olomouc, Czech Republic
}

\begin{abstract}
Objective: To examine the adverse events reporting practices of nurses in Slovakia.

Design: A cross-sectional study.

Methods: Data were collected using the Hospital Survey on Patient Safety Culture between December 2017 and July 2018. Registered nurses $(n=1073)$ from both public and private hospitals across the Slovak Republic were included in the sample. Data were analyzed through descriptive and inductive statistics using SPSS 25.0.

Results: A relationship was established between nurse-reported patient safety levels and different unit types, along with nurse overtime levels. A significant relationship was confirmed between the number of events reported by a nurse and nurse education levels, length of clinical practice, hospital size, and both hospital and unit type. Likewise, a significant relationship was verified between the reporting of near-misses and the hospital type, the hospital size and overtime hours.

Conclusions: Nurses have a responsibility to advance patient safety, and this includes adverse event and near-miss reporting. Particular nurse and organizational factors have been identified which enhance reporting patterns and patient safety. Consideration of these factors when planning the nurse workforce can affect overall patient safety.
\end{abstract}

Keywords: Adverse events; Hospital; Hospital Survey on Patient Safety Culture; Nurse; Report

\section{Introduction}

In recent decades, patient safety has become an increasingly important global issue - and it is widely recognized as a global challenge (Andersson et al., 2018). Healthcare may be understood as a complex dynamic system that consists of networks of components that interact nonlinearly over multiple scales and may produce unintended results. The complex system may behave differently, which depends on its initial conditions and feedback. It is acknowledged that patients can be exposed to complex nonlinear interactions on different levels (e.g., government, hospital, family) in the provision of health care, and that these interactions may result in unintended consequences - such as adverse events (Lipsitz, 2012). Thousands of patients are affected by adverse events annually (Makary and Daniel, 2016) with one in ten resulting in the extension of hospitalization, and 7\% resulting in death (de Vries et al., 2008). In the United States, adverse events are the third most common cause of patient mortality in healthcare (Makary and Daniel, 2016).

Nurses play a significant role in promoting patient safety, due in part to their direct and continuous patient contact (Kim et al., 2016). As a professional group, nurses engage in activities which enhance patient safety, including reporting of adverse events and coordination of care. The occurrence of serious adverse events and unintentional mistakes is still relatively high, but can be avoided with effective preventative measures (Andersson et al., 2018; Kim et al., 2016), which include the identification of underlying cause through effective reporting systems. It is internationally acknowledged that the number of reported adverse events is much lower than the number that actually occurs (Ko and Yu, 2017; McLennan et al., 2016). Recognized factors which impact adverse event reporting rates by nurses are teamwork and communication issues, staff shortages and overtime rates (Shin et al., 2018; Zarea et al., 2018), insufficient management support (Ko and $\mathrm{Yu}, 2017$ ), lack of time or knowledge (Lederman et al., 2013),

\footnotetext{
* Corresponding author: Dominika Kalánková, Comenius University in Bratislava, Jessenius Faculty of Medicine, Department of Nursing, Malá Hora 5, 03601 Martin, Slovak Republic; e-mail: kalankova1@uniba.sk

" Dominika Kalánková and Marcia Kirwan should be considered joint first author.

http://doi.org/10.32725/kont.2020.033

Submitted: 2020-06-11 - Accepted: 2020-09-01 • Prepublished online: 2020-09-02

KONTAKT 23/2: 97-103 • EISSN 1804-7122 • ISSN 1212-4117

(c) 2020 The Authors. Published by University of South Bohemia in České Budějovice, Faculty of Health and Social Sciences.

This is an open access article under the CC BY-NC-ND license.
} 
increased turnover and frequent changes in nursing documentation (Zarea et al., 2018), and nurse education levels (Aiken et al., 2012). Many of these factors should be considered by nurse managers when examining adverse event reporting rates in their areas. Effective leadership within organizations can contribute to ensuring safer work environments in which nurses are not afraid to report their mistakes, thus resulting in increased patient safety levels and ultimately an overall reduction in the number of adverse events (Ko and Yu, 2017).

Internationally, the focus of patient safety is frequently on preventative strategies which aim to reduce the risk of adverse events or near-misses. In response to a European Council Recommendation on patient safety (2009/C 151/01), the Health Care Surveillance Authority in the Slovak Republic, much like many new European Union states, sought to address this issue within the context of their country. They issued Methodological guidance (no. 3/2014) that focused on the implementation of a reporting system for adverse events in institutional healthcare. According to this document, Slovak nurses were required to report all adverse incidents which occur in those patients under the nurses' care, while in contrast near-misses are reported only on a voluntarily basis (Office of the Inspector General, 2014). The introduction of this and similar reporting systems across Europe and in a broader international context has not been without its challenges for both nurses and managers. However, this is particularly true in eastern European states where the nursing profession has undergone a recent and rapid transformation in line with EU requirements - against a background of ongoing social and political change. Nurse shortages in Slovakia and other countries have been addressed through increased nurse overtime, and the introduction, or reinstatement, of different grades of nurses such as practical nurses. The educational preparation of these nurses is significantly shorter and more practically based than the bachelor education RNs who practice beside them - although the competencies are now very similar. The influence of these changes on patient safety efforts is not entirely certain. This research looks at how Slovak nurses, within a context of a reducing nurse workforce, have responded to the patient safety agenda and how nurse characteristics and working arrangements have influenced this response. Based on this, the study aimed to explore adverse events reporting among registered nurses (RNs) in the Slovak Republic, more specifically: (a) to describe adverse events reporting practices by nurses in the Slovak Republic and (b) to examine how nurse characteristics and working arrangements impact the number of events reported during the last twelve months (actual number of adverse events reported), the frequency of events reported (near-misses reported), along with nurse-reported patient safety level.

\section{Materials and methods}

A cross-sectional study design was used to examine the adverse events reporting practices of nurses in Slovakia. The study included seven general hospitals (private provider) and five teaching hospitals (public provider) in the Slovak Republic. Following ethical approval, researchers requested and were granted access to hospital staff for the purposes of this research. A total of 128 care units were involved, of which 72 care units were situated in teaching and university hospitals, and 56 care units in general hospitals. RNs within these units were selected purposively if they: (a) provided nursing care to adult patients, (b) worked in medical-surgical care units, intensive care units, and elderly care units, (c) were willing to take part. RNs were excluded if they: (a) held a managerial position, (b) worked in pediatric or gynaecology-obstetric care units. To determine adequate sample size, an online sample size calculator (Qualtrics ${ }^{\circledR}$ ) was used. In the Slovak Republic, there are approximately 41000 nurses. We used the confidence interval of $95 \%$ and, due to the size of the sample, the study obtains a margin of error of $\pm 5 \%$. The sample size was set to be at a minimum of 381 respondents.

\section{Data collection}

The study was conducted between December 2017 and July 2018. Data were collected using the "Hospital Survey on Patient Safety Culture" (HSOPS) questionnaire. The instrument identifies twelve dimensions of patient safety culture as well as two additional items. The HSOPS is validated for use with all categories of healthcare professionals (Sorra and Nieva, 2004). However, in our study, the instrument was used only with RNs. The instrument consists of 42 items in nine parts (A-I) through which patient safety culture can be measured. In this article, we focus on adverse events reporting, so we used only D, E, G, and H parts of the instrument.

\section{Data analysis}

Data analysis was performed using SPSS version 25.0. Descriptive statistics (average, median, frequencies and SD) and sample characteristics are reported here. Data were analyzed for pattern and the frequency of missing data at the participant and item level. Data imputation was not indicated at any point. Missing data ranged from $0.5 \%$ to $0.9 \%$, demonstrating high acceptability of the HSOPS instrument. In line with the study objectives, the data were tested using analysis of variance (ANOVA) and multiple regression analysis focusing on the frequency of near-miss events reported, nurse-reported patient safety grade, and the number of events reported during the last twelve months. These outcomes were examined in relation to predefined nurse factors such as education level, specialization training, overtime hours during the past three months, total job experience, current job experience, and organizational factors such as unit and hospital type, and hospital size. Pearson chi-squared test $\left(\chi^{2}\right)$ was used to compare the positive proportion of nurse-reported patient safety level and the number of events reported between the particular unit types. The results were tested on the significance level $p \leq 0.05$.

\section{Results}

Overall, 1,582 questionnaires were distributed, and 1,145 were returned. Of these, 72 questionnaires were not completed and therefore were excluded, leaving a total of 1,073 RNs (response rate $-65.86 \%$ ). Sample characteristics are reported fully in Table 1.

\section{Adverse event reporting}

Descriptive statistics were used to present the frequencies of the selected parts (D, E, and G) of the HSOPS instrument. On a scale from never to always, RNs stated the most (30.9\%) that they sometimes reported adverse events when they occur. Within the subscale frequency of events reported (part D), RNs declared that they "rarely" report all categories of near misses: a mistake made but caught and corrected before affecting the patient (30.3\%); a mistake made but with no potential harm to the patient (29.3\%), and a mistake made that could harm the patient but does not (29.7\%). On average, RNs evalu- 
Table 1. Sample characteristics $(n=1,073)$

\begin{tabular}{|c|c|c|c|}
\hline Variable & & $N=1073$ & $\%$ \\
\hline \multirow{8}{*}{ Nurse experience in current unit (years) } & Up to 5 years & 280 & 27.3 \\
\hline & 6-10 years & 205 & 20.0 \\
\hline & $11-15$ years & 123 & 12.0 \\
\hline & $26-20$ years & 120 & 11.7 \\
\hline & More than 21 years & 296 & 28.9 \\
\hline & M \pm SD (range) & & \\
\hline & $20.0 \pm 8.1(1-45)$ & & \\
\hline & Median - 22.0 & & \\
\hline \multirow{9}{*}{ Nurse experience in nursing (years) } & Up to 5 years & 126 & 12.6 \\
\hline & $6-10$ years & 91 & 9.1 \\
\hline & $11-15$ years & 104 & 10.4 \\
\hline & $26-20$ years & 151 & 15.1 \\
\hline & More than 21 years & 531 & 52.9 \\
\hline & $M \pm S D$ (range) & & \\
\hline & $13.8 \pm 6.9(1-45)$ & & \\
\hline & Median - 11.0 & & \\
\hline & & $N=1073$ & $\%$ \\
\hline \multirow{5}{*}{ Unit type } & Surgical & 337 & 31.4 \\
\hline & Medical & 368 & 34.3 \\
\hline & Elderly care & 43 & 4.0 \\
\hline & ICU & 239 & 22.2 \\
\hline & Other & 86 & 8.1 \\
\hline \multirow{4}{*}{ Nurse education level } & Secondary vocational education & 313 & 29.2 \\
\hline & Higher education & 322 & 30.0 \\
\hline & Bachelor degree & 203 & 18.9 \\
\hline & Master degree or higher & 235 & 21.9 \\
\hline \multirow{2}{*}{ Nurse specialization training programme } & Yes & 691 & 64.4 \\
\hline & No & 382 & 35.6 \\
\hline \multirow{3}{*}{ Overtime hours* } & None & 296 & 27.6 \\
\hline & Less than 12 hours & 328 & 30.6 \\
\hline & More than 12 hours & 449 & 41.8 \\
\hline \multirow{2}{*}{ Hospital type } & Teaching hospital (public provider) & 785 & 73.2 \\
\hline & General hospital (private provider) & 288 & 26.8 \\
\hline \multirow{3}{*}{ Hospital size } & Less than 300 beds & 135 & 12.6 \\
\hline & Between 301 and 500 beds & 136 & 12.7 \\
\hline & More than 500 beds & 80 & 74.7 \\
\hline
\end{tabular}

ated the patient safety level in their current workplace as "very good" (44.5\%) followed by "acceptable" (42.0\%), and reported 1 to 2 events in the past 12 months (39.4\%). Evaluation of the nurse-reported patient safety level and the number of events reported in relation to the unit type are reported in Table 2.

\section{Results from ANOVA and multiple regression analysis}

The results are presented in Tables 3 and 4. According to ANOVA, there were statistically significant differences between the nurse-reported patient safety level across units $(p=0.000)$. The highest level of patient safety ("acceptable" to "very good") was reported by RNs working in intensive care units $(3.79 \pm 0.74)$. The lowest level of patient safety ("acceptable" to "poor") was reported by RNs working in elderly care units $(3.20 \pm 0.70)$. A significant relationship was noted between the nurse-reported patient safety level and overtime in the past three months $(p=0.028)$. The highest level of patient safety was reported by RNs who did not have any overtime in the past three months $(3.64 \pm 0.75)$, while the lowest was presented by RNs who had 12 and more hours (3.55 \pm 0.78$)$. A significant relationship was also confirmed between the number of events reported during the last 12 months and the unit type $(p=0.000)$. RNs who worked in elderly care units reported between three and five adverse events in the previous year $(3.38 \pm 1.85)$. The lowest number of events reported (1-2 events) during the last 12 months was recorded by RNs working in intensive care units $(1.50 \pm 0.91)$. A significant relationship was also confirmed between the number of events reported in the past 12 months and the hospital size $(p=0.006)$. The highest number of reported adverse events in the last year was recorded by RNs working at hospitals with less than 300 beds $(2.26 \pm 1.26)$. For the subscale which exams nearmiss reporting (frequency of events reported), statistically significant differences were confirmed in relation to hospital size $(p=0.003)$. RNs working at hospitals with 301 to 500 beds reported the highest number of near-miss events $(3.75 \pm 1.01)$. 
Table 2. Comparison of patient safety grade and number of events reported within the unit type

\begin{tabular}{|c|c|c|c|c|c|c|c|}
\hline Outcome variable & Items & $\begin{array}{c}\text { Surgical } \\
\text { departments } \\
(n=337)\end{array}$ & $\begin{array}{c}\text { Medical } \\
\text { departments } \\
(n=368)\end{array}$ & $\begin{array}{l}\text { Elderly care } \\
\quad(n=43)\end{array}$ & $\begin{array}{c}\text { ICU } \\
(n=239)\end{array}$ & $\begin{array}{l}\text { Other } \\
(n=86)\end{array}$ & Pearson $\chi^{2}$ \\
\hline $\begin{array}{l}\text { Nurse-reported } \\
\text { patient safety } \\
\text { grade }\end{array}$ & $\begin{array}{c}\text { Excellent } \\
\text { Very good } \\
\text { Acceptable } \\
\text { Poor } \\
\text { Failing }\end{array}$ & $\begin{array}{c}2(0.6 \%) \\
24(7.1 \%) \\
144(42.7 \%) \\
136(40.4 \%) \\
31(9.2 \%)\end{array}$ & $\begin{array}{c}11(3.0 \%) \\
52(14.1 \%) \\
199(54.1 \%) \\
97(26.4 \%) \\
9(2.4 \%)\end{array}$ & $\begin{array}{c}1(2.3 \%) \\
1(2.3 \%) \\
13(30.4 \%) \\
25(58.1) \\
3(6.9 \%)\end{array}$ & $\begin{array}{c}19(7.9 \%) \\
138(57.8 \%) \\
58(24.3 \%) \\
19(7.9 \%) \\
5(2.1 \%)\end{array}$ & $\begin{array}{c}10(11.6 \%) \\
9(10.5 \%) \\
29(33.7 \%) \\
28(32.6 \%) \\
10(11.6 \%)\end{array}$ & $\begin{aligned} \chi^{2} & =78.664 \\
p & =0.000\end{aligned}$ \\
\hline $\begin{array}{l}\text { Number of events } \\
\text { reported }\end{array}$ & $\begin{array}{c}\text { None } \\
1-2 \text { events } \\
3-5 \text { events } \\
6-10 \text { events } \\
11-20 \text { events } \\
\text { More than } 21 \text { events }\end{array}$ & $\begin{array}{c}111(32.9 \%) \\
108(32.0 \%) \\
72(21.4 \%) \\
33(9.8 \%) \\
12(3.6 \%) \\
1(0.3 \%)\end{array}$ & $\begin{array}{c}123(33.4 \%) \\
118(32.1 \%) \\
77(20.9 \%) \\
33(8.9 \%) \\
5(1.4 \%) \\
12(3.3 \%)\end{array}$ & $\begin{array}{c}2(4.6 \%) \\
5(11.6 \%) \\
27(62.8 \%) \\
4(9.4 \%) \\
3(7.0 \%) \\
2(4.6 \%)\end{array}$ & $\begin{array}{l}95(39.7 \%) \\
96(40.3 \%) \\
27(11.3 \%) \\
17(7.1 \%) \\
2(0.8 \%) \\
2(0.8 \%)\end{array}$ & $\begin{array}{c}40(46.5 \%) \\
30(34.8 \%) \\
11(12.7 \%) \\
2(2.2 \%) \\
1(1.6 \%) \\
2(2.2 \%)\end{array}$ & $\begin{array}{c}\chi^{2}=104.183 \\
p=0.000\end{array}$ \\
\hline
\end{tabular}

Table 3. Dependent variables in relation to the selected socio-demographic data - results from ANOVA

\begin{tabular}{lccc} 
& Nurse-reported patient safety level & Number of events reported & Frequency of events reported \\
\hline Unit type & $\mathbf{0 . 0 0 0}$ & $\mathbf{0 . 0 0 0}$ & 0.231 \\
\hline Education & 0.850 & 0.815 & 0.863 \\
Specialization training programme & 0.240 & 0.253 & 0.352 \\
\hline Overtime hours & $\mathbf{0 . 0 2 8}$ & 0.786 & 0.153 \\
\hline Experience (total) & 0.420 & 0.695 & 0.619 \\
Experience (current) & 0.380 & 0.754 & 0.611 \\
\hline Hospital size & 0.416 & $\mathbf{0 . 0 0 6}$ & $\mathbf{0 . 0 0 3}$ \\
Hospital type & 0.361 & 0.258 & 0.322 \\
\hline
\end{tabular}

Table 4. Dependent variables in relation to the selected socio-demographic data - results from multiple regression analysis

\begin{tabular}{|c|c|c|c|c|c|c|}
\hline & \multicolumn{2}{|c|}{$\begin{array}{l}\text { Nurse-reported patient safety } \\
\text { level }\end{array}$} & \multicolumn{2}{|c|}{ Number of events reported } & \multicolumn{2}{|c|}{ Frequency of events reported } \\
\hline & $\beta$ coefficient & $p$ value & $\beta$ coefficient & $p$ value & $\beta$ coefficient & $p$ value \\
\hline Unit type & 0.236 & 0.347 & 0.120 & 0.326 & 0.156 & 0.477 \\
\hline Education & -0.001 & 0.978 & 0.087 & 0.044 & -0.009 & 0.827 \\
\hline Specialization training programme & 0.326 & 0.256 & 0.157 & 0.562 & 0.453 & 0.256 \\
\hline Overtime hours & -0.038 & 0.352 & 0.019 & 0.662 & -0.081 & 0.046 \\
\hline Experience (total) & -0.013 & 0.885 & -0.269 & 0.009 & 0.183 & 0.057 \\
\hline Experience (current) & 0.072 & 0.143 & 0.064 & 0.232 & -0.003 & 0.948 \\
\hline Hospital size & 0.071 & 0.310 & 0.075 & 0.311 & 0.163 & 0.016 \\
\hline Hospital type & 0.310 & 0.155 & 0.171 & 0.026 & 0.321 & 0.000 \\
\hline
\end{tabular}

Multiple regression analysis was conducted to further examine the relationship between near-miss reporting practices as measured by the frequency of events reported scale, nurse-reported patient safety level, the number of actual adverse events reported, and selected potential predictors (socio-demographic characteristics). The results are presented in Table 4. Model 1 ( $R^{2}=0.374 ;$ Adj $\left.R^{2}=0.369 ; F=51.44\right)$ revealed that the number of adverse events reported was significantly associated with the following predictors - nurse education level, length of the clinical practice, and hospital type. A higher number of events was reported by RNs with higher education in nursing than secondary medical education $(\beta=0.087 ; p=0.044)$. Also, RNs working at public teaching or university hospitals reported a lower number of events compared to those working at private general hospitals $(\beta=$
0.171; $p=0.026)$. RNs who were much more experienced in clinical practice (related to the length of clinical practice experience) reported a lower number of events $(\beta=-0.269 ; p=$ 0.009). Interestingly, more experienced $\mathrm{RNs}$ had a higher score in the subscale measuring near-miss reporting and frequency of events reported ( $\beta=0.183 ; p=0.047)$, and appear to be more likely to report near-misses than actual adverse events. In Model $2\left(R^{2}=0.264 ;\right.$ Adj $\left.R^{2}=0.249 ; F=42.16\right)$, a significant relationship was confirmed between the subscale frequency of events reported (near misses) and overtime hours. RNs who had less than 12 hours of overtime reported more near-misses $(\beta=0.81 ; p=0.046)$. A higher score in the subscale was obtained from RNs working at general hospitals $(\beta=0.321$; $p=0.000)$. A significant association was also found in relation to hospital size. RNs working in smaller hospitals 
(up to 500 beds) had a higher score for near-miss reporting $(\beta=0.163 ; p=0.016)$. In Model $3\left(R^{2}=0.113 ;\right.$ Adj $R^{2}=0.002$; $F=1.203)$, no significant relationships were proved between selected predictors and nurse-reported patient safety level.

\section{Discussion}

Adverse event prevention remains a priority issue in healthcare, and it is acknowledged that reporting adverse events significantly enhances the provision of safe care to patients (Pham et al., 2013). However, according to McLennan et al. (2016), reporting is often inadequate and unreliable. Nonetheless, the results of our study show better reporting rates amongst Slovak nurses than other international studies where RNs reported fewer adverse events (McLennan et al., 2016; Prang and Jelsness-Jørgensen, 2014). This may be a result of the Slovak Republic's strong commitment to the Recommendation of the Council of European Union on patient safety (no. 2009/C151/01), and the introduction of reporting systems for adverse events at a time when nurses in that country were particularly open to change.

Although these results are encouraging it must be noted that Slovak RNs rarely reported near misses. This underlines that there remains a lot of work to be done on reporting practices of nurses in Slovakia. In our study, RNs reported patient safety levels in their units to be in the range from "acceptable" to "very good", similar to previous studies (Hammer et al., 2011; Nie et al., 2013). The differences noted across units, however, are important for nurse managers planning the nurse workforce and care delivery. The nurse reported patient safety levels are highest in ICUs and surgical units. This would suggest an increased focus on patient safety is required in medical and care of the elderly units. This study revealed certain nurse demographics which are associated with improved safety practices. In Slovakia, nurses with a higher education in nursing than secondary medical education recognize and report more events. It is possible that this occurs because these nurses identify more events, and are more conscious of the global patient safety agenda. This implies that patient safety increases with a better-educated workforce - and reflects findings from other studies where nurse education levels are seen to have a critical impact on the assessment of patient safety level and adverse events (Aiken et al., 2012; Kirwan et al., 2013). These studies found that the quality of provided care, patient safety grade, patient mortality, and other complications were adversely impacted by lower numbers of nurses educated to bachelor level. In countries such as Slovakia - where there is a move towards enhancing the workforce through the introduction of practical nurses or similar - this point is of particular importance. Nurse managers must be vigilant of the potential impact of this move on patient safety. In Slovakia, a change in legislation (Regulation No. 95/2018) led to a sudden re-categorization of those formally known as 'nurse assistants' to 'practical nurses'. The educational preparation of these nurses is significantly shorter and more practically based than the bachelor education RNs who practice beside them (although the competencies are now very similar). International studies indicate that attempts to address nurse shortages by increasing proportions of less-educated nurses, such as licensed or practical nurses, may be a short-sighted strategy. Needleman et al. (2002), Griffiths et al. (2019) and others warn that different grades of nurses cannot be seen as equivalent, and higher proportions of these nurses in the workforce are associated with higher levels of complications, including mortality levels. In the Slovak Republic, several factors, such as teamwork, management, and staffing levels, have been confirmed as influential for overall patient safety (Sováriová Soósová et al., 2017). Nurse managers have a responsibility to respond to these findings in their roles as nurse leaders in hospitals.

The observed impact of nurse overtime rates is of enormous significance to nurse managers. Where overtime rates are high, the nurse reported patient safety level is lower. A study conducted by Shin et al. (2018) found that RN overtime hours may negatively affect the quality of provided care, as well as the health and well-being of RNs. In our study we verified that if RNs had more than 12 overtime hours in the past three months, they reported a lower level of patient safety. A study by Sováriová Soósová et al. (2017) also demonstrated the negative impact of the overtime hours on patient safety. Other studies show that lower staffing levels result in higher overtime rates for existing RNs. Staff shortages in turn, often lead to higher levels of adverse events in healthcare (Shin et al., 2018; Zarea et al., 2018). We identified that RNs who had more than 12 hours of overtime also had a lower score in the subscale frequency of events reported. Currently, in Slovakia and internationally, there is a nurse shortage, so we considered this as the main contributing factor to the high number of nurse overtime hours. An over-reliance on this method of staffing is likely to lead to poor patient outcomes in the longterm. Nurse managers should use this evidence to influence decision-making and policy regarding nurse numbers.

The number of events reported in the past year was found to be influenced mainly by the unit type. It is recognized that ICUs are workplaces which require rapid and critical assessments and activities. Thus, patient safety may be more at risk, resulting in higher numbers of adverse events (Espin et al., 2010). In our research, this was not confirmed. This may be mainly due to the low number of patients per $\mathrm{RN}$ in intensive care units - whereas in standard care units, on average, 2 RNs are responsible for the care of 15 patients. Patient-nurse ratio and its impact on patient safety and the occurrence of adverse events has been reported in many previous studies (Aiken et al., 2012; Kirwan et al., 2013).

Other factors which influence the numbers of events reported were hospital type and length of clinical practice. More experienced RNs reported fewer events in the past 12 months compared to their less experienced colleagues. It is unclear why this might be the case, although perhaps less experienced nurses are more confident when it comes to reporting than their more experienced colleagues - despite differences in their age. The number of events reported, along with the frequency of near-miss reporting, was also associated with the hospital size. This might be explained through differences in patient acuity, turnover or length of patient stay in different sized hospitals. RNs working in large hospitals provide continuous nursing care to patients and their families, and therefore a shortage of staff can cause complex problems. In essence, hospitals with a higher number of beds are more impacted by staff shortages - leading to an increased number of adverse events (Shin et al., 2018).

In our study, we identified a significant relationship between near-miss reporting and hospital type. RNs working in general hospitals reported more near-misses than RNs working in teaching or university hospitals. This contrasted with other studies, where no such differences were identified (Espin et al., 2010; Lee and Doran, 2017). Based on the findings, it seems that the hospital type and hospital size have an important role in the adverse events reporting according to its identification in both categories. 
Interestingly, it was shown in this study that the completion of a specialization training programme was not statistically significant. This is an important finding as the practice of additional specialization by completing one of 12 specialist training programmes is commonplace in Slovakia. Nurse managers should consider that this additional training does not necessarily impact patient safety. Sováriová Soósová's et al. study (2017) confirmed that if nurses indicated a low level of patient safety, the number of events reported increased. The opposite was confirmed in our study. Through our results, we highlight that nurses in the study are engaged in adverse event reporting and accept this as part of their role. However, in Slovak hospitals, the implementation of the near-misses reporting into clinical nursing practice is not yet accepted.

The study has several limitations. The sample size might be considered one such limitation. We invited all university and teaching hospitals under public ownership - and included all of them where access was granted. However, we addressed only seven private hospitals based on geographic location. Thus it may be difficult to generalize the results. Another limitation is that during data collection, the self-reported instrument was used. Using this method, causal relationships cannot be proven beyond doubt, but our large sample size and statistically significant finding lend veracity to the results presented here.

\section{Conclusions}

Adverse events are a challenge in contemporary healthcare. As relevant information can be drawn from them, there is a need to raise awareness that they should be regularly and always reported. It is not enough, however, to report only errors that have arisen, but it is also essential to focus on reporting near-misses. Identifying the factors that may affect reporting of adverse events/near misses can help management to correct them before they happen - and consequently build a strong barrier to preventing their occurrence. For further international research, our study could act as an example of how to work with adverse event data and how to reach conclusions regarding the reporting of adverse events in other countries.

\section{Conflict of interests}

The authors have no conflict of interests to declare.

\section{Ethical considerations}

The study was approved by the institutional board committee (EC no. 30/2017). Permission to use the HSOPS instrument was obtained from AHRQ (2017). Written access and consent was obtained from all hospitals. Respondents were only included following verbal informed consent, and all questionnaires were anonymous. Strict data protection procedures and ethical considerations were adhered to.

\section{Ako je hlásenie nežiaducich udalostí v Slovenskej republike ovplyvnené charakteristikami sestier a pracovnými podmienkami: prierezová štúdia}

\section{Súhrn}

Ciel: Preskúmat́ postupy hlásenia nežiaducich udalostí sestrami na Slovensku.

Dizajn: Prierezová štúdia.

Metódy: Údaje boli zbierané prostredníctvom nástroja Hospital Survey on Patient Safety Culture medzi decembrom 2017 a júlom 2018. Do súboru boli zaradené registrované sestry $((n=1073)$ z verejných aj súkromných nemocníc z celej Slovenskej republiky. Údaje boli analyzované pomocou deskriptívnej a induktívnej štatistiky s použitím programu SPSS 25.0.

Výsledky: Vztáah bol preukázaný medzi sestrami hláseným stupňom bezpečnosti pacientov a rôznymi typmi oddelení, spolu s počtom nadčasových hodín. Signifikantný vztahah bol potvrdený medzi počtom sestrami hlásených udalostí a vzdelaním sestier, dlízkou klinickej praxe, vel'kostou nemocnice a typom oddelenia a nemocnice. Súčasne bol verifikovaný vztah medzi hlásením takmer-pochybení a typom a vel'kostou nemocnice a počtom nadčasových hodín.

Záver: Sestry sú zodpovedné za zlepšovanie bezpečnosti pacientov, čo zahŕňa hlásenie nežiaducich udalostí a takmer-pochybení. Boli identifikované konkrétne faktory na strane sestier a organizačné faktory, ktoré zlepšujú postupy hlásenia ako aj bezpečnost́ pacientov. Zváženie daných faktorov pri plánovaní pracovnej zátaže sestier môže ovplyvnit' celkovú bezpečnost' pacientov.

Kl'účové slová: hlásenie; Hospital Survey on Patient Safety Culture; nemocnica; nežiaduce udalosti; sestra

\section{References}

1. Aiken LH, Sermeus W, Van den Heede K, Sloane DM, Busse R, McKee M, et al. (2012). Patient safety, satisfaction and quality of hospital care: cross sectional surveys of nurses and patients in 12 countries in Europe and the United States. BMJ 344: e1717. DOI: 10.1136/bmj.e1717.

2. Andersson $\AA$, Frank C, Willman AML, Sandman P-O, Hansebo G (2018). Factors contributing to serious adverse events in nursing homes. J Clin Nurs 27(1-2): e354-e362. DOI: 10.1111/ jocn.13914.

3. Council Recommendation 2009/C 151/01 on patient safety, including prevention and control of healthcare associated infections (2009). Official Journal of the European Union 52: $1-7$.
4. de Vries EN, Ramrattan MA, Smorenburg SM, Gouma DJ, Boermeester MA (2008). The incidence and nature of in-hospital adverse events: a systematic review. Qual Saf Health Care 17(3): 216-223. DOI: 10.1136/qshc.2007.023622.

5. Espin S, Wickson-Griffiths A, Wilson M, Lingard L (2010). To report or not to report: A descriptive study exploring ICU nurses' perceptions of error and error reporting. Intensive and Critical Care Nursing 26: 1-9. DOI: 10.1016/j.iccn.2009.10.002.

6. Griffiths P, Maruotti A, Saucedo AR, Redfern OC, Ball JE, Briggs J, et al. (2019). Nurse staffing, nursing assistants and hospital mortality: retrospective longitudinal cohort study. BMJ Quality and Safety 28: 609-617. DOI: 10.1136/ bmjqs-2018-008043.

7. Hammer A, Ernstmann N, Ommen O, Wirtz M, Manser T, Pfeiffer Y, et al. (2011). Psychometric properties of the Hospital Survey on Patient Safety Culture for hospital 
management (HSOPS M). BMC Health Serv Res 11(165): 1-10. DOI: $10.1186 / 1472-6963-11-165$.

8. Kim MY, Kim YM, Kang S-W (2016). A survey and multilevel analysis of nursing unit tenure diversity and medication errors. J Nurs Manag 24(5): 634-645. DOI: 10.1111/jonm.12366.

9. Kirwan M, Matthews A, Scott A (2013). The impact of the work environment of nurses on patient safety outcomes: A multilevel modelling approach. Int J Nurs Stud 50(2): 253-263. DOI: 10.1016/j.ijnurstu.2012.08.020.

10. Ko Y, Yu S (2017). The relationship among perceived patients' safety culture, intention to report errors, and leader coaching behaviour of nurses in Korea: A pilot study. J Patient Saf 13(3): 175-183. DOI: 10.1097/PTS.0000000000000224.

11. Lederman R, Dreyfus S, Matchan J, Knott JC, Milton SK (2013). Electronic error-reporting systems: A case study into the impact on nurse reporting of medical errors. Nurs Outlook 61(6): 417-426. DOI: 10.1016/j.outlook.2013.04.008.

12. Lee CT-S, Doran DM (2017). The role of interpersonal relations in healthcare team communication and patient safety: A proposed model of interpersonal process in teamwork. Can J Nurs Res 49(2): 75-93. DOI: 10.1177/0844562117699349.

13. Lipsitz LA (2012). Understanding health care as a complex system: The foundation for unintended consequences. JAMA 308(3): 243-244. DOI: 10.1001/jama.2012.7551.

14. Makary MA, Daniel M (2016). Medical error - the third leading cause of death in the US. BMJ 353: i2139. DOI: 10.1136/bmj. i2139.

15. McLennan SR, Diebold M, Rich LE, Elger BS (2016). Nurses' perspectives regarding the disclosure of errors to patients: A qualitative study. Int J Nurs Stud 54: 16-22. DOI: 10.1016/j. ijnurstu.2014.10.001.

16. Methodological guidance no. 3/2014 focusing on the system of the implementation of reporting of errors, mistakes and adverse events in institutional healthcare (2014). Health Care Surveillance Authority in the Slovak Republic. [online] [cit. 2020-01-22]. Available at: http://www.udzs-sk.sk/metodickeusmernenia

17. Needleman J, Buerhaus P, Mattke S, Stewart M, Zelevinsky K (2002). Nurse-Staffing Levels and the Quality of Care in
Hospitals. New England Journal of Medicine 346(22): 17151722. DOI: $10.1056 / \mathrm{NEJMsa012247.}$

18. Nie Y, Mao X, Cui H, He S, Li J, Zhang M (2013). Hospital survey on patient safety culture in China. BMC Health Serv Res 13(1): 228-238. DOI: 10.1186/1472-6963-13-228.

19. Office of the Inspector General (2014). Adverse Events in Skilled Nursing Facilities: National Incidence Among Medicare Beneficiaries. Department of Health and Human Services, National Institutes of Health. [online] [cit. 2020-01-22]. Available at: https://oig.hhs.gov/oei/reports/oei-06-11-00370. pdf

20. Pham JC, Girard T, Pronovost PJ (2013). What to do with healthcare incident reporting systems. J Pub Health Res 2(3): 154-159. DOI: 10.4081/jphr.2013.e27.

21. Prang IW, Jelsness-Jørgensen L-P (2014). Should I report? A qualitative study of barriers to incident reporting among nurses working in nursing home. Geriatr Nurs 35(6): 441-447. DOI: 1016/j.gerinurse.2014.07.003.

22. Regulation No 95/2018 (2018). Ministry of Health of the Slovak Republic. [online] [cit. 2020-01-22]. Available at: http://www. epi.sk/zz/2018-95/znenie-20180401\#Share

23. Shin S, Park J-H, Bae S-H (2018). Nurse staffing and nurse outcomes: a systematic review and meta-analysis. Nurs Outlook 66(3): 273-282. DOI: 10.1016/j.outlook.2017.12.002.

24. Sorra JS, Nieva VF (2004) Hospital Survey on Patient Safety Culture (Prepared by Westat, under Contract No.290-96-0004). [online] [cit. 2020-01-22]. Available at: http://www.ahrq.gov/ sites/default/files/wysiwyg/professionals/quality-patientsafety/patientsafetyculture/hospital/resources/hospcult.pdf

25. Sováriová Soósová M, Zamboriová M, Murgová A (2017) Hospital patient safety culture in Slovakia. Ošetrovatel'stvo: teória, výskum, vzdelávanie 1(1): 12-19.

26. Zarea K, Mohammadi A, Beiranvand S, Hassani F, Baraz S (2018). Iranian nurses' medication errors: A survey of the types, causes, and the related factors. International Journal of African Nursing Sciences 8: 112-116. DOI: 10.1016/j. ijans.2018.05.001. 